\title{
A new species of Corydoras Lacépède, 1803 (Siluriformes: Callichthyidae) from the upper rio Paraná basin, Brazil
}

\author{
Luiz F. C. Tencatt ${ }^{1}$, Marcelo R. Britto ${ }^{2}$ and Carla S. Pavanelli ${ }^{1}$
}

A new species of Corydoras is described from three tributaries of the rio Ivaí drainage, upper rio Paraná basin, Paraná State, Brazil. The new species can be distinguished from most of its congeners by the presence of three nasal pores. Other diagnostic features are the lower number of serrations in posterior margin of pectoral and dorsal spines and presence of four to six small black blotches along the midline of the flank. The possible mimetic relationship between the new species and Characidium heirmostigmata is discussed.

Uma espécie nova de Corydoras é descrita de três tributários da drenagem do rio Ivaí, bacia do alto rio Paraná, estado do Paraná, Brasil. A espécie nova se diferencia da maioria de suas congêneres por apresentar três poros nasais. Outras características diagnósticas são o menor número de serrilhas na margem posterior dos espinhos peitoral e dorsal e presença de quatro a seis manchas pretas pequenas ao longo da linha mediana do flanco. A possível relação mimética entre a espécie nova e Characidium heirmostigmata é discutida.

Key words: Characidium heirmostigmata, Corydoradinae, Mimicry, Rio Ivaí, Taxonomy.

\section{Introduction}

Corydoras Lacépède, 1803 is the most species-rich genus of Siluriformes, currently with about 170 nominal species (Eschmeyer, 2013). Despite of some attempts performed in the last 40 years to elucidate the taxonomy and systematics of the group (e.g., Nijssen, 1970; Nijssen \& Isbrücker, 1980; Britto, 2003; Alexandrou et al., 2011), interrelationships of Corydoras species are still poorly known (Britto et al., 2007). Currently, four valid Corydoras species could be recognized from upper rio Paraná basin: C. aeneus (Gill, 1858), C. difluviatilis Britto \& Castro, 2002, C. ehrhardti Steindachner, 1910 and C. flaveolus Ihering, 1911. Analyses from samples collected by Nupélia staff(Núcleo de Pesquisas em Limnologia, Ictiologia e Aquicultura, Universidade Estadual de Maringá) from rio Ivaí drainage reveals a new species of Corydoras, which is described herein.

\section{Material and Methods}

Measurements were obtained using digital caliper to the nearest 0.1 millimeter. Morphometric and meristic data were taken following Reis (1997), excepting the length of the anal-fin spine that is absent in all Corydoradinae. The length of the pectoral-fin spine was included in the morphometric analysis and was taken from its base to its distal tip. Morphometrics are reported as percentages of standard length (SL) and head length (HL). Homology of barbels follows Britto \& Lima (2003). Some specimens were cleared and stained (c\&s) according to protocol of Taylor \& Van Dyke (1985) for osteological analysis. Osteological terminology was based on Reis (1998), excepting by using parieto-supraoccipital instead of supraoccipital (Arratia \& Gayet, 1995) and compound pterotic instead of pteroticsupracleithrum (Aquino \& Schaefer, 2002). Counts of vertebrae followed Britto et al. (2009). In the description, numbers in brackets represent the total number of specimens with those counts. Numbers with an asterisk refer to the counts of the holotype. Comparative data of Corydoras diphyes were obtained from Axenrot \& Kullander (2003). Institutional abbreviations are: AI, Asociatión Ictiológica La Plata, La Plata; LBP, Laboratório de Biologia de Peixes da Universidade Estadual Paulista, Botucatu; DZSJRP, Coleção de Peixes do Departamento de Zoologia e Botânica

\footnotetext{
${ }^{1}$ Universidade Estadual de Maringá, Coleção de Peixes do Núcleo de Pesquisas em Limnologia, Ictiologia e Aquicultura. Av. Colombo, 5790, 87020-900 Maringá, PR, Brazil. luiztencatt@hotmail.com, carlasp@nupelia.uem.br

${ }^{2}$ Universidade Federal do Rio de Janeiro, Museu Nacional, Departamento de Vertebrados, Setor de Ictiologia. Quinta da Boa Vista s/n, São Cristóvão, 20940-040 Rio de Janeiro, RJ, Brazil. mrbritto2002@yahoo.com.br
} 
da Universidade Estadual Paulista "Júlio de Mesquita Filho", São José do Rio Preto; MCP, Museu de Ciências e Tecnologia da Pontifícia Universidade Católica do Rio Grande do Sul, Porto Alegre; MNRJ, Museu Nacional, Rio de Janeiro, Rio de Janeiro; MZUSP, Museu de Zoologia da Universidade de São Paulo, São Paulo; NUP, Coleção Ictiológica do Núcleo de Pesquisas em Limnologia, Ictiologia e Aquicultura da Universidade Estadual de Maringá, Maringá; ZUEC-PIS, Coleção de Peixes do Museu de Zoologia da Universidade Estadual de Campinas, Campinas; ZUFMS-PIS, Coleção Zoológica de Referência da Universidade Federal do Mato Grosso do Sul, Campo Grande.

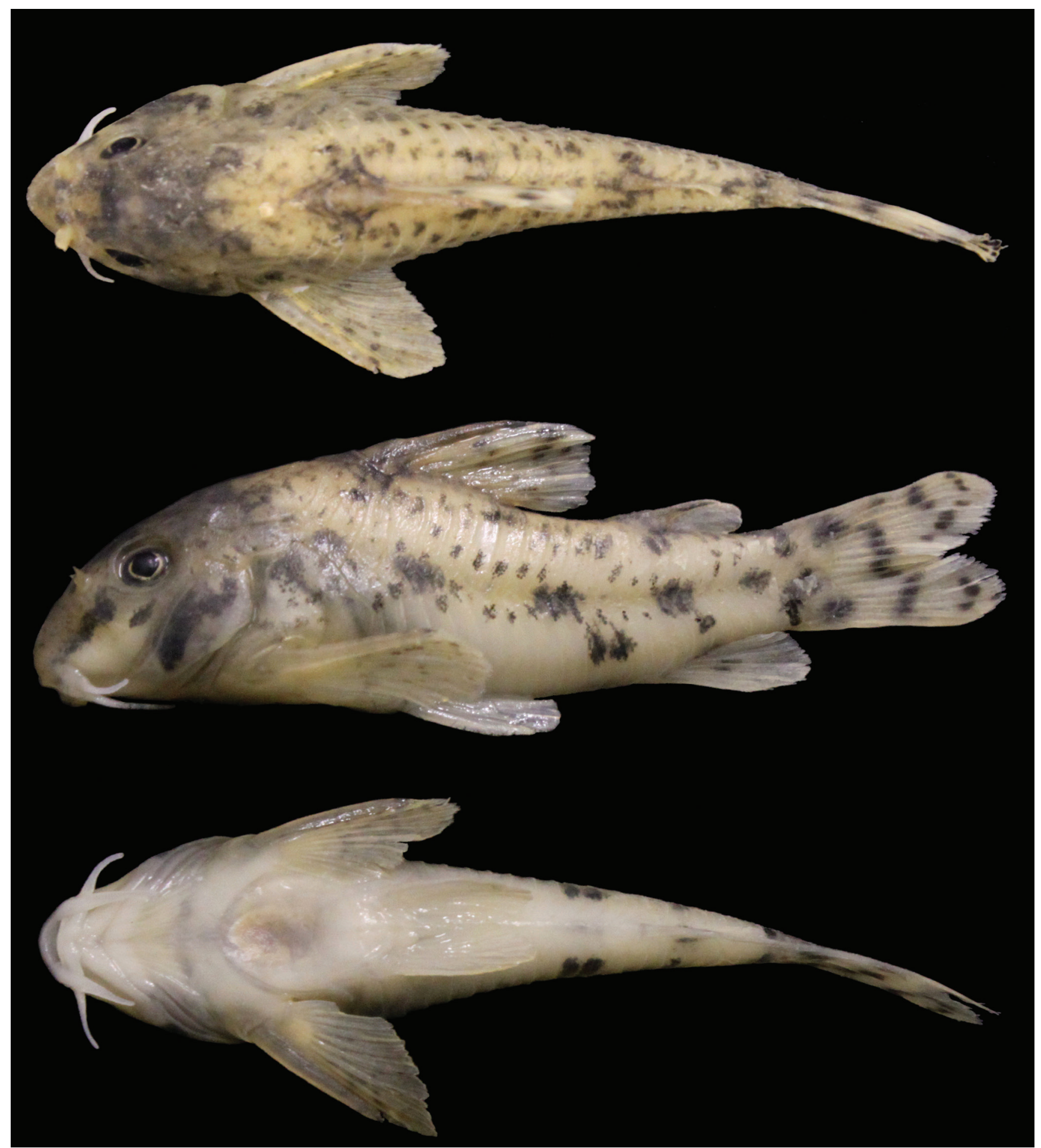

Fig. 1. Corydoras lacrimostigmata, holotype, MNRJ 40725, 31.8 mm SL, Brazil, Paraná, Cândido Abreu, rio Maria Flora, tributary to rio Ubazinho, rio Ivaí basin. Dorsal, lateral and ventral views. 


\section{Results \\ Corydoras lacrimostigmata, new species Figs. 1, 2a}

Corydoras flaveolus not Ihering, 1911. - Graça \& Pavanelli, 2007: 10, 113, 114 [Brazil, Paraná State, checklist, identification key, brief description, distribution, maximum standard length, photo in lateral view]

Holotype. MNRJ 40725, 31.8 mm SL, Brazil, Paraná, Cândido de Abreu, rio Maria Flora, tributary to rio Ubazinho, rio Ivaí basin, 2436’32”S 51¹5’32”W, 9 Mar 2013, L.F.C. Tencatt, G.C. Deprá \& F.T. Mise.

Paratypes. All collected in Brazil, Paraná State, Cândido de Abreu, rio Ivaí basin, except when noticed. MCP 47851, 5, 25.8-29.8 mm SL, rio Nestor, 24³2'26”S 51²0'09'W, 22 Nov 1994, Nupélia staff. MNRJ 40726, 16, 25.7-34.3 mm SL, rio Nestor, 24²8'S 5054'W, 22 Nov 1994, Nupélia staff. NUP 1408, 5, 26.1-31.2 mm SL, rio Nestor, 24³2'26"S 51²0'09'W, 22 Nov 1994, Nupélia staff. NUP 1436, 9, 26.0-27.6 mm SL, rio Nestor, 24³2'05'S 51¹9'39'W, 22 Nov 1994, Nupélia staff. NUP 1446, 26, 17.5-34.3 mm SL, rio Nestor, 24²8'S 5054’W, 22 Nov 1994, Nupélia staff. NUP 5484, 2, 27.2-28.3 mm SL, Prudentópolis, rio Barra Grande, 245' 41'’S 5107'34'W, 3 Apr

Tabela 1. Morphometric data of Corydoras lacrimostigmata. $\mathrm{n}=$ number of specimens and $\mathrm{SD}=$ standard deviation.

\begin{tabular}{lcccc}
\hline & $\mathrm{n}$ & Holotype & Low-High & Mean \pm SD \\
\hline Standard length (mm) & 21 & 31.8 & $26.1-34.3$ & $30.1 \pm 2.6$ \\
\multicolumn{4}{c}{ Percents of standard length } \\
Depth of body & 21 & 33.0 & $30.6-36.3$ & $33.6 \pm 1.6$ \\
Predorsal distance & 21 & 49.1 & $44.7-49.1$ & $46.8 \pm 1.2$ \\
Prepelvic distance & 21 & 45.9 & $43.3-49.5$ & $45.6 \pm 1.4$ \\
Preanal distance & 21 & 79.9 & $76.8-83.3$ & $80.7 \pm 1.6$ \\
Preadipose distance & 21 & 81.4 & $77.4-83.0$ & $80.1 \pm 1.7$ \\
Length of dorsal spine & 21 & 20.8 & $14.3-22.1$ & $18.5 \pm 1.9$ \\
Length of pectoral spine & 21 & 21.4 & $17.2-25.1$ & $21.4 \pm 1.7$ \\
Length of adipose-fin spine & 21 & 9.1 & $6.7-10.7$ & $8.5 \pm 1.1$ \\
Depth of caudal peduncle & 21 & 13.2 & $11.6-14.2$ & $13.2 \pm 0.6$ \\
Length of dorsal-fin base & 21 & 15.7 & $14.0-17.8$ & $16.4 \pm 0.9$ \\
Dorsal to adipose distance & 21 & 19.5 & $15.8-19.9$ & $17.8 \pm 1.2$ \\
Maximum cleithral width & 21 & 28.0 & $25.1-29.4$ & $26.8 \pm 1.0$ \\
Head length & 21 & 44.0 & $39.2-44.0$ & $41.2 \pm 1.5$ \\
Length of maxillary barbel & 21 & 10.7 & $6.8-16.6$ & $10.0 \pm 2.7$ \\
& Percents of head length & & \\
Head depth & 21 & 70.7 & $70.3-82.1$ & $75.4 \pm 3.4$ \\
Least interorbital distance & 21 & 25.0 & $23.5-28.6$ & $26.5 \pm 1.4$ \\
Horizontal orbit diameter & 21 & 20.7 & $20.6-26.5$ & $22.9 \pm 1.9$ \\
Snout length & 21 & 36.4 & $29.7-38.3$ & $34.8 \pm 1.9$ \\
Least internarial distance & 21 & 8.6 & $7.1-13.3$ & $9.3 \pm 1.4$ \\
\hline & & & & \\
\hline
\end{tabular}

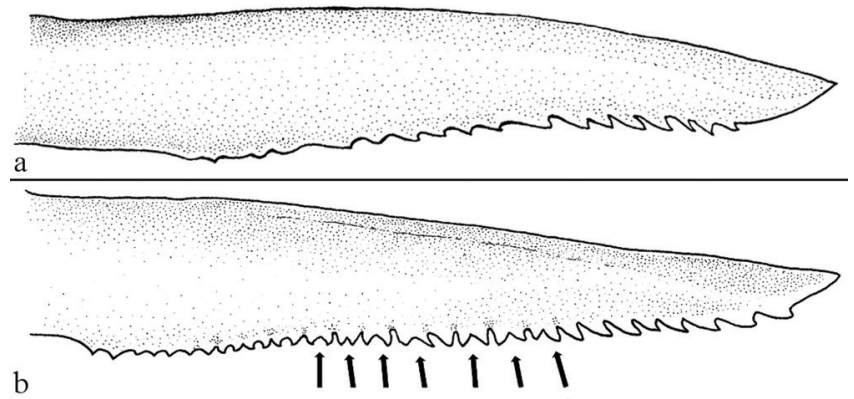

Fig. 2. Pectoral-fin spine of Corydoras lacrimostigmata (a), NUP 14657, paratype, $30.9 \mathrm{~mm} \mathrm{SL}$, showing the serrations in posterior margin of the right spine $(6.0 \mathrm{~mm})$ and Corydoras flaveolus (b), LBP 14596, $33.5 \mathrm{~mm} \mathrm{SL}$, showing the serrations in posterior margin of the right spine $(8.0 \mathrm{~mm})$. Arrows indicate bifid serrations.

2007, C. H. Zawadzi \& W. J. da Graça. NUP 14657, 3 c\&s, 30.9-34.5 mm SL, rio Nestor, 24³2'05"S 51¹9'39”W, 22 Nov 1994, Nupélia staff. ZUEC-PIS 7550, 3, 26.5-30.5 mm SL, rio Nestor, 24³2'05'S 51¹9'39”W, 22 Nov 1994, Nupélia staff. NUP 3976, 2, 26.5-30.0 $\mathrm{mm} \mathrm{SL}$; same data as the holotype.

Diagnosis. Corydoras lacrimostigmata can be distinguished from its congeners, with exception of C. carlae, C. ehrhardti, C. flaveolus, C. longipinnis, C. nattereri, C. paleatus, and C. vittatus, by the presence of three nasal pores ( $v s$. two). The new species can be distinguished from C. carlae, $C$. ehrhardti, C. longipinnis, C. nattereri, C. paleatus, and $C$. vittatus by the presence of four to six small rounded black blotches along the midline of flank ( $v s$. midline of flank with three large black blotches in C. carlae, C. ehrhardti, $C$. longipinnis, and C. paleatus; longitudinal dark stripe in $C$. nattereri; and anterior portion spotted and posterior portion with posterior margin of plates blackened, forming a rough dark stripe in some specimens of $C$. vittatus). The new species can be distinguished from $C$. flaveolus by the lower number of serrations on posterior margin of pectoral-fin spine (16-19 vs. 27-36) and on posterior margin of dorsal-fin spine (7-10 vs. 15-22); and by the presence of simple serrations on posterior margin of pectoral-fin spine (vs. presence of simple and bifid serrations). See additional diagnostic features in discussion.

Description. Morphometric data presented in Table 1. Head compressed with slightly convex dorsal profile; triangular in dorsal view. Snout slightly pointed. Head profile convex from snout to tip of posterior process of parieto-supraoccipital. Profile slightly convex along dorsal-fin base. Postdorsal-fin body profile concave to adipose-fin spine; concave from this point to caudal-fin base. Ventral profile of body nearly straight from isthmus to pectoral girdle; slightly convex from this point until pelvic girdle. Profile nearly straight from pelvic girdle to base of first anal-fin ray; slightly concave until caudal-fin 
base. Body roughly elliptical in cross section at pectoral girdle, gradually becoming more compressed toward caudal fin.

Eye rounded, located dorso-laterally on head; orbit delimited dorsally by frontal and sphenotic, ventrally by infraorbitals. Anterior and posterior nares close to each other, only separated by a flap of skin. Anterior naris tubular. Posterior naris close to anterodorsal margin of orbit, separated from it by a distance equal to diameter of naris. Mouth small, subterminal, width nearly equal to bony orbit diameter. Maxillary barbel short, not reaching anteroventral limit of gill opening. Outer mental barbel slightly longer than maxillary barbel. Inner mental barbel fleshy, base separated to its counterpart; insertion of barbell in middle of lower lip. Small rounded papillae covering entire surface of all barbels, upper and lower lips, and isthmus.

Mesethmoid short, posterior portion partially exposed and bearing minute odontodes. Nasal slender, curved laterally, anterior portion of inner margin laminar; mesial border contacting only frontal; with three nasal pores. Frontal elongated, narrow, width less than half entire length; anterior projection short, size smaller than nasal length; epiphyseal branch of supraorbital canal short, pore opening located mesially on frontals. Frontal fontanel large, oval; posterior tip slightly entering anterior margin of parieto-supraoccipital. Parieto-supraoccipital wide, posterior process long and contacting nuchal plate. Two laminar infraorbitals with minute odontodes; infraorbital 1 large, anterior portion with very large expansion; infraorbital 2 small, postero-ventral margin contacting supra-preopercle, dorsal tip slender, contacting sphenotic. Interopercle covered by thick layer of skin, somewhat triangular, anterior projection welldeveloped. Preopercle slender, elongated; minute odontodes sparse on external surface. Opercle elongated in shape, width nearly equal or smaller than half of its length; free margin smooth, without serrations and covered by small odontodes. Anteroventral portion of cleithrum exposed; posterolateral portion of scapulocoracoid exposed; minute odontodes sparse on exposed areas. Vertebral count 23(3); ribs 5(3), first pair conspicuously large.

Four branchiostegal rays decreasing in size posteriorly. Hypobranchial 2 somewhat triangular, tip ossified and directed towards anterior portion, posterior margin cartilaginous; ossified portion well developed, about twice size cartilaginous portion. Five ceratobranchials with expansions increasing posteriorly; ceratobranchial 1 with small process on anterior margin of mesial portion; ceratobranchial 3 notched on

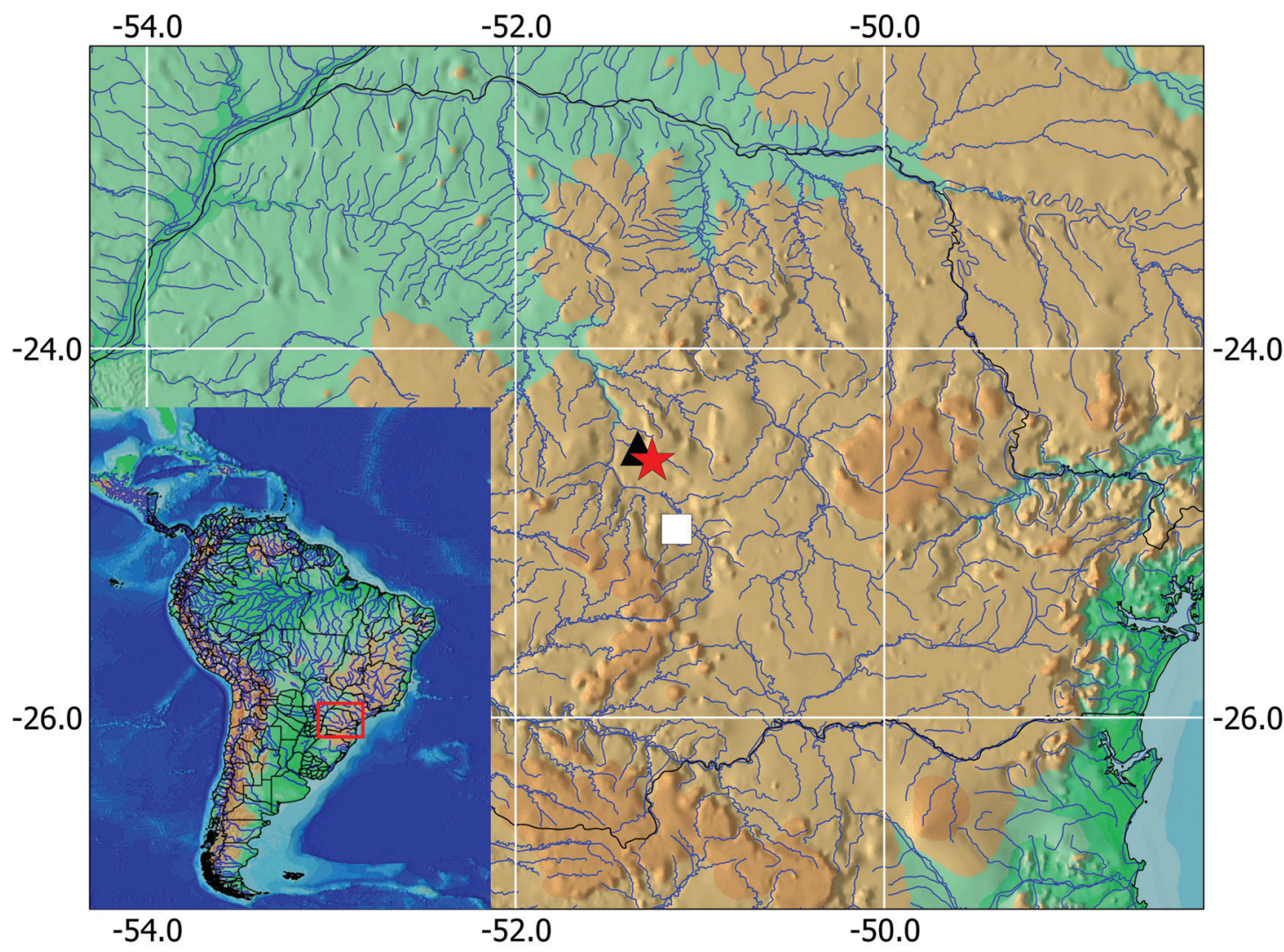

Fig. 3. Map showing geographic distribution of Corydoras lacrimostigmata. Red star represents the type locality, rio Maria Flora, the triangle represents rio Nestor and the square represents rio Barra Grande, upper rio Paraná basin, Paraná. Each symbol may represent more than one locality. 


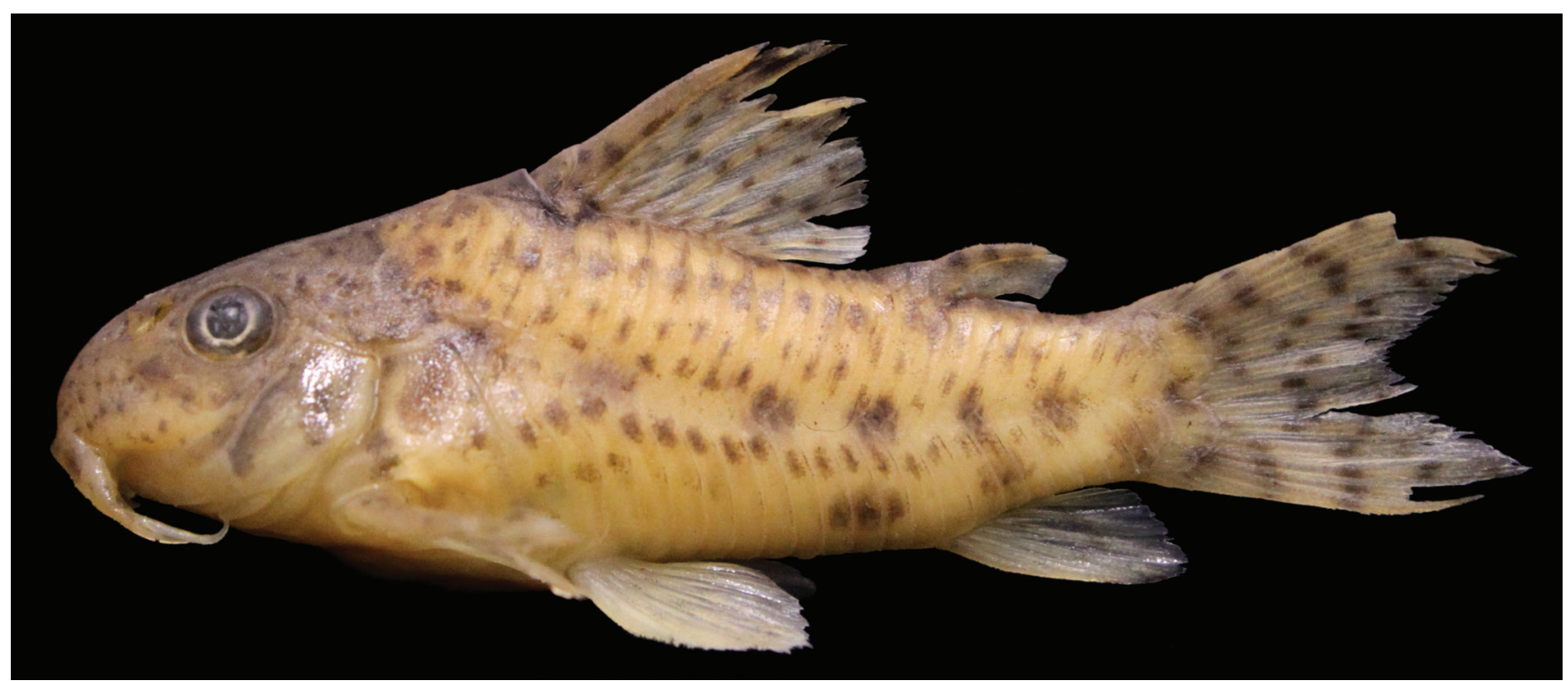

Fig. 4. Lateral view of Corydoras flaveolus, LBP 14596, $31.6 \mathrm{~mm} \mathrm{SL}$, showing general shape of the body and color patter in lateral view.

postero-lateral margin; ceratobranchial 5 toothed on postero-dorsal surface, 25-28(3) teeth aligned in one row. Four epibranchials with similar size; epibranchial 2 slightly larger than others, lacking small pointed process on laminar expansion of posterior margin; epibranchial 3 without uncinate process on laminar expansion of posterior margin. Two wide pharyngobranchials, pharyngobranchial 3 with large triangular process on posterior margin. Upper tooth plate oval; 30-37(3) teeth aligned in two rows on postero-ventral surface.

Dorsal-fin rays II, $8 *(20)$, II, $9(1)$, posterior margin of dorsalfin spine with 7-10 serrations, disposed on distal half of the spine; nuchal plate exposed with minute odontodes; spinelet short; spine short, adpressed distal tip not surpassing base of last branched dorsal-fin ray, posterior margin with small odontodes. Pectoral-fin rays I,8; posterior margin of pectoral spine with 16-19 moderate developed serrations, disposed along entire length of posterior margin or absent close to the insertion of spine (Fig. 2a). Pelvic-fin rays i,5. Anal-fin rays i,6. Caudal-fin rays i,12,i, generally three dorsal and ventral procurrent rays, respectively; bilobed, with superior lobe slightly larger than inferior one; lobes with rounded distal border.

Three laterosensory canals on trunk; first ossicle tubular, second ossicle laminar and last lateral-line canal encased in third dorsolateral body plate. Body plates with minute odontodes scattered over exposed area, a conspicuous line of odontodes confined on posterior margins; dorsolateral body plates 23(3), 24*(18); ventrolateral body plates 20(2), 21*(19); dorsolateral body plates along dorsal-fin base 5(9), $6 *(12)$; dorsolateral body plates between adipose and caudal fin 7(3), $8 *(18)$; preadipose platelets $2(7), 3 *(13), 4(1)$, adipose spine opposed to anal-fin insertion; small platelets covering base of caudal-fin rays; small platelets disposed dorsally and ventrally between junctions of lateral plates on posterior portion of caudal peduncle. Anterior margin of orbit with platelets, above posterior portion of lateral ethmoid and above the junction of frontal and lateral ethmoid. Ventral surface of the body without platelets.

Color in alcohol. Ground color of body brownish yellow, with top of the head dark brown. Tip of the snout generally with rounded black spots; scattered chromatophores not forming conspicuous spots in some specimens; few specimens lacking spots on snout. Diffuse dark stripe between corner of mouth and anterior margin of orbit. Posterior region of infraorbital 1 with a drop-shaped dark blotch. Black spots on dorsal portion of the head in some specimens. Region of nasal bone dark brown. Opercle with clear border; anterior portion dark brown. Upper portion of dorsolateral plates black or brownish blotched. Dorsal series of four black or brownish blotches, first on anterior portion of dorsal-fin base, second on posterior portion of dorsal-fin base, third on adipose-fin base and fourth on caudal-fin base. Midline of flank with four to six small rounded black or brownish blotches. Inferior portion of ventrolateral body plates generally black or brownish spotted posteriorly to pelvic fin. Dorsal and ventral portions of the posterior-most region of the caudal peduncle blackened. Ventral portion of caudal peduncle with a darkened region just posterior to anal fin. Dorsal and pectoral fins scarcely mottled. Tip of the spine and first branched dorsal-fin rays, including membranes, blackened. Pelvic fin generally hyaline. Adipose fin generally with hyaline membrane; with a darkened area on distal portion of membrane in some specimens. Anal fin generally black or brownish spotted; hyaline in some specimens. Middle portion of caudal- fin base with small black 
dot. Origin of each caudal-fin lobe with black blotch. Caudal fin with one to three irregular black bars.

Color in life. Similar to preserved specimens. Yellowish ground color of body slightly light and dark stripe between corner of mouth and anterior margin of orbit more evident than in preserved specimens.

Distribution. Corydoras lacrimostigmata is known from rio Ivaí basin, a tributary of the rio Paraná, in the State of Paraná, Brazil (Fig. 3).

Etymology. From the Latim, the epithet lacrima, meaning tear, plus stigmata, meaning marks (plural of stigma), make allusion to the diffuse dark stripe between corner of mouth and anterior margin of orbit and the drop-shaped dark blotch on the posterior portion of infraorbital 1, which seem to be tears. A noun in apposition.

\section{Discussion}

Corydoras lacrimostigmata have a very similar color pattern to C. cochui Myers \& Weitzman, 1954, from the upper rio Araguaia basin, C. diphyes Axenrot \& Kullander, 2003 from Monday and Acaray Rivers, C. garbei Ihering, 1911, from rio São Francisco basin, and mainly to C. flaveolus, from rio Piracicaba basin. Despite the great resemblance between these species, the new species can be clearly distinguished by osteological and morphological features. The presence of three nasal pores, an uncommon condition for the genus, distinguishes the new species from $C$. cochui and $C$. garbei which present two pores. In addition, C. garbei presents a very developed

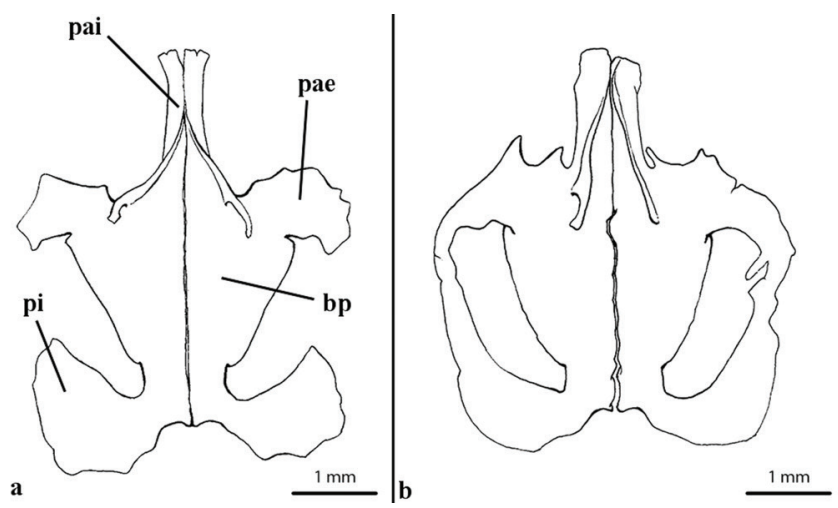

Fig. 5. Dorsal view of the pelvic girdle of (a) Corydoras lacrimostigmata and (b) Corydoras flaveolus, showing the slender anterior internal process of the basipterygium (pai) in C. lacrimostigmata and thicker in C. flaveolus. Additionally, the presence of conspicuous distance between external anterior process (pae) and the dorsal ischiac process (pi) of the basipterygium (bp) in C. lacrimostigmata and the fused condition in C. flaveolus. Scale bars $=1 \mathrm{~mm}$. anterior expansion of infraorbital 1 , which is only moderately developed in Corydoras lacrimostigmata. Contrary to Britto (2003: 136), who stated that C. flaveolus possess only two nasal pores, specimens examined herein present three nasal pores. This feature could not be examined in $C$. diphyes, since no specimens of this species were available for study. The new species can be clearly distinguished from $C$. diphyes by its shorter dorsal-fin spine (14.3-22.1\% in SL vs. 26.3-30.8\% in SL) and for presenting black spots on the pectoral fin ( $v s$. hyaline).

Initially, the new species was identified as Corydoras flaveolus by Graça \& Pavanelli (2007). However analyzing material of $C$. flaveolus from the rio Tietê basin, including tributaries of rio Piracicaba, some morphological differences that allowed to diagnose the two species became evident. The snout of Corydoras lacrimostigmata is slightly pointed and the dorsal profile of the head is gradually concave (Fig. 1), whereas in C. flaveolus the snout is roughly rounded and the dorsal profile of the head is abruptly concave (Fig. 4). In addition to the higher number of serrations in dorsal and pectoral spines in C. flaveolus (see diagnosis), the serrations are well-developed (vs. weak developed) and sometimes bifid (Fig. 2b), whereas the new species present only simple serrations (Fig. 2a). Other useful feature to diagnose the two species is the length of the outer mental barbel, which is smaller in the new species, distant from anteroventral limit of gill opening ( $v s$. large, reaching or slightly surpassing the anteroventral limit of gill opening in C. flaveolus). The general shape of the body is also useful to distinguish the new species from C. flaveolus, which possesses robust body (Fig. 4) while Corydoras lacrimostigmata possesses a slender body (Fig. 1).

The pelvic girdle conspicuously differs between the new species and C. flaveolus. The anterior internal process of the basipterygium is slender in the new species (Fig. 5a). Corydoras flaveolus presents the anterior internal process of the basipterygium thicker (Fig. 5b). Other remarkable feature is the distance between the external anterior process and the dorsal ischiac process of the basipterygium. In C. flaveolus these two processes can be very close to each other or even fused (Fig. 5b), while the new species displays these processes distant from each other in all examined specimens (Fig. 5a).

Even the color pattern of Corydoras lacrimostigmata presents some differences from C. flavelous. In the new species, the spots, when present, are restricted to the snout tip and, in some specimens, to the top of the head, while C. flaveolus presents spots from the snout tip to the region of dorsal-fin base. Also, the flank of C. flaveolus is densely mottled with black chromatophores and, in some specimens, the dorsolateral series of plates is almost completely dusky. Specimens of the new species possesses less mottled flank. The same is observed on dorsal and caudal fins, which are densely covered of spots and bars, respectively, whereas the new species presents just a few spots and bars. 


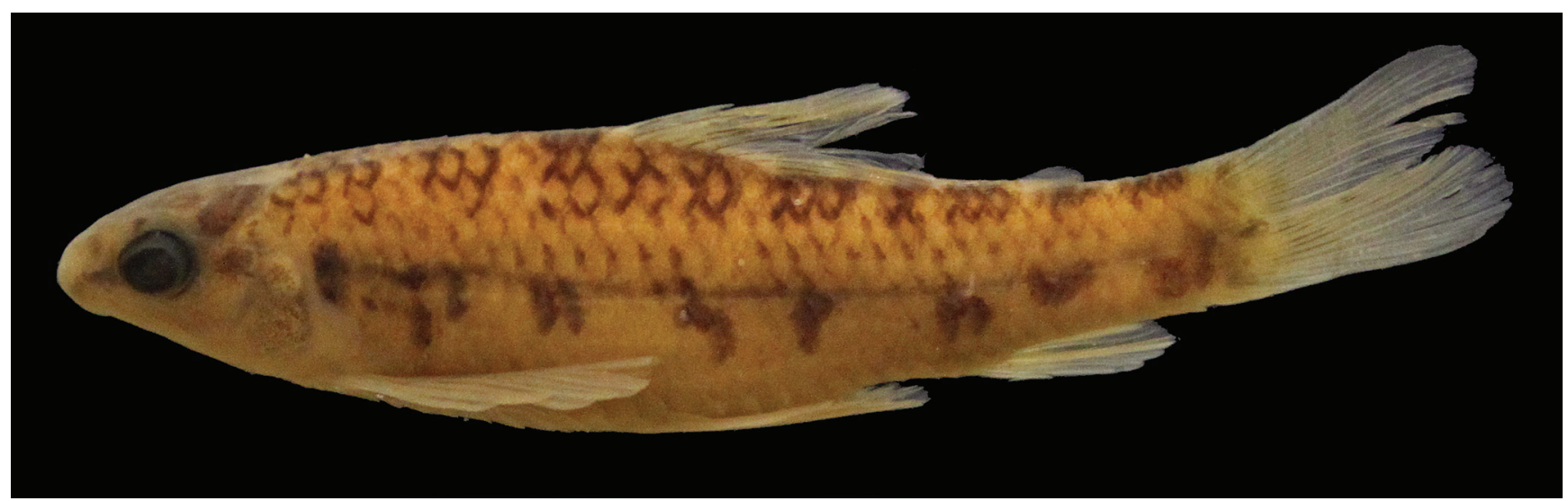

Fig. 6. Lateral view of Characidium heirmostigmata, NUP 1393, paratype, $39.8 \mathrm{~mm}$ SL, showing color pattern and general shape of the body.

In the description of $C$. diphyes and Otocinclus mimulus, Axenrot \& Kullander (2003) commented about the mimetic relation between both species and another pairs of syntopic Corydoras and Otocinclus species: O. flexilis Cope, 1894 and C. paleatus (Jenyns, 1842), O. affinis Steindachner, 1877 and C. nattereri Steindachner, 1877, and O. xakriaba Schaefer, 1997 and C. garbei Ihering, 1911. The latter pair seems to evidence an uncommon case of mimetic association, since the shared similarity is perceived between adult specimens of $O$. xakriaba and juveniles of $C$. garbei (Axenrot \& Kullander, 2003: 269-270). Corydoras lacrimostigmata seems to possess similar mimetic association with Characidium heirmostigmata Graça \& Pavanelli, 2008. Both species were captured together in syntopy in the rio Barra Grande and in the rio Nestor (W. J. da Graça, pers. obs. on specimens of the rio Barra Grande). The resemblance is more evident in the color pattern. The two species have a midlateral series of small black or brownish blotches on flank, a small black dot in the middle of caudal-fin base, dorsal series of black or brownish blotches and a diffuse dark stripe between corner of mouth and anterior margin of orbit (Fig. 6). Furthermore, the new species present caudal-fin lobes with conspicuously rounded distal border, which is generally pointed in Corydoras (see Fig. 4), very similar to the caudal-fin lobes in Characidium heirmostigmata (see Fig. 1).

Maier et al. (2008) presented a checklist of fish species in rio Barra Bonita, tributary to the rio Ivaí. Thirteen of the 31 listed species are possible new species, some of them included in the list of 50 possible new species from the upper rio Paraná basin mentioned by Langeani et al. (2007). However, some of the 13 species listed by Maier et al. (2008) were not included in Langeani et al. (2007), such as some potentially new Hypostomus species. Other example is $C$. heirmostigmata which was not listed in both studies.

The endemic species in the rio Ivaí basin can be attributed to some interesting geomorphological factors, mainly in its middle and upper regions, which are inserted into the Serra Geral (also known as Serra da Boa Esperança) as described by Maack (1981).
Some tectonic processes, allied to the properties of the local rocks, caused inflections on the ground, including the Ponta Grossa Arch, and also numerous waterfalls, like the São João and São Francisco falls, both higher than $50 \mathrm{~m}$ (Maack, 1981), which may have caused the isolation of some fish populations. However, it is important to note that knowledge of the fish fauna of the rio Ivaí basin is precarious because very few collections have been carried out there, mainly in its tributaries (see Galves et al., 2009: fig. 1). The description of Corydoras lacrimostigmata highlights the requirement of further sampling and studies at the rio Ivaí basin, a relatively large, yet poorly known tributary to the upper rio Paraná basin concerning its fish fauna.

Comparative material. A list of the comparative material is available in Britto (2003). In addition, the following material was examined: Argentina. Corydoras longipinnis: AI 221, holotype, $59.5 \mathrm{~mm} \mathrm{SL}$, Santiago del Estero, Río Sali. NUP 14439, 2, 28.6-32.4 mm SL, San Miguel de Tucumán, Arroyo Los Perez. NUP 14440, 2 c\&s, 29.9-33.4 mm SL, San Miguel de Tucumán, Arroyo Pampa-Mayo. Brazil. $C$. areio: MNRJ 20694, 2, 27.0-41.5 mm SL, Mato Grosso, rio Parnaíba. NUP 10227, 1, 17.6 mm SL, Mato Grosso, córrego Cancela. ZUFMSPIS 1105, 5, 33.7-44.4 mm SL, Mato Grosso do Sul, stream without toponymy. ZUFMS-PIS 1314, 17, 34.4-41.9 mm SL, Mato Grosso do Sul, córrego São João. C. carlae: NUP 711, 1, 47.9 mm SL, Paraná, rio Tormenta. NUP 4425, 1 c\&s, 45.0 mm SL, Paraná, rio Tormenta. NUP 4868, 2, 44.7-46.6 mm SL, Paraná, rio Adelaide. NUP 4870, 2, 51.153.5 mm SL, Paraná, rio Adelaide. NUP 4871, 1, 50.4 mm SL, Paraná, rio Adelaide. NUP 4872, 1, $46.1 \mathrm{~mm} \mathrm{SL}$, Paraná, rio Adelaide. NUP 4874, 1, 48.8 mm SL, Paraná, rio Tormenta. NUP 4875, 3, 43.8-50.1 mm SL, Paraná, rio Tormenta. NUP 4877, 3, 44.1-50.6 mm SL, Paraná, rio Tormenta. NUP 4878, 1, $51.5 \mathrm{~mm}$ SL, Paraná, rio Tormenta. NUP 4880, 1, 30.2 mm SL, Paraná, rio Guarani. NUP 4897, 1, 51.0 mm SL, Paraná, rio Tormenta. C. cochui: MZUSP 89055, 6, 18.7-23.6 mm SL, Goiás, rio do Peixe II. C. difluviatilis: MCP 16994, 23, 25.7-41.6 mm SL, 2 c\&s, 37.9-39.1 mm SL, Minas Gerais, arroio a $45 \mathrm{~km} \mathrm{~S} \mathrm{de} \mathrm{Montes}$ Claros, pela estrada BR-125 em direção a Bocaiúva. MCP 28500, 29, 22.0-45.1 mm SL, 2 c\&s, 24.9-45.1 mm SL, Goiás, Córrego Grande. 
NUP 1105, 37, 16.0-36.8 mm SL, Goiás, Corumbá Reservoir. NUP 9966, 27, 28.4-34.3 mm SL, Minas Gerais, rio Guarda-Mor. C. ehrhardti: NUP 11255, 15, 36.5-46.8 mm SL, Paraná, rio São Pedro. C. ellisae: NUP 3239, 42, 21.0-47.8 mm SL, Mato Grosso, córrego Forquilha. $C$. flaveolus: DZSJRP 7932, 4, 13.9-31.6 mm SL, São Paulo, córrego do Anzol. DZSJRP 8448, 7, 23.5-32.3 mm SL, São Paulo, córrego da Lapa. LBP 2862, 29, 21.6-38.2 mm SL, São Paulo, rio Alambari. LBP, 13, 25.8 32.9 mm SL, São Paulo, rio Passa-Cinco. LBP 14596, 12, 31.2-37.1 mm SL, 3 c\&s, 33.2-33.8 mm SL, São Paulo, rio Capivara. MNRJ 21538, 3 , 28.7-35.9 mm SL, São Paulo, córrego do Óleo. MZUSP 47925, 15 of 22, 33.0-35.1 mm SL, São Paulo, rio Bauru. NUP 84, 2, 25.6-30.0 mm SL, São Paulo, rio Alambari. C. garbei: MCP 16942, 28, 24.0-34.8 mm SL, Minas Gerais, stream without toponymy. MCP 16993, 27, 25.3-37.2 mm SL, 3 c\&s, 27.6-31.9 mm SL, Bahia, rio Pau da Colher. MNRJ 18089, 16, 20.1-27.4 mm SL, Minas Gerais, lagoa Perta-Pé. C. hastatus: NUP 6862, 116, 13.1-20.7 mm SL, Mato Grosso, baía Caiçara. C. maculifer: NUP 8970, 2, 42.0-46.0 mm SL, Tocantins, ribeirão Xambioazinho. $C$. multimaculatus: MCP 29025, 2, 20.1-25.4 mm SL, Minas Gerais, rio Peruaçu. C. pantanalensis: NUP 12593, 21, 38.7-51.2 mm SL, Mato Grosso do Sul, tributary to rio Miranda. C. splendens: NUP 12990, 1, $43.7 \mathrm{~mm}$ SL, Goiás, tributary to rio Araguaia. C. steindachneri: MCP 16597, 2, 32.2-37.9 mm SL, Santa Catarina, sanga em Mude-Baixa. $C$. stenocephalus: MNRJ 3625, 3, 31.2-62.3 mm SL, Amazonas, rio Javari. Peru. C. acutus: MNRJ 3985, 2, 47.1-54.8 mm SL, Sancho-caño.

\section{Acknowledgments}

We thank Jorge Casciotta and Adriana Almirón (AI), Claudio Oliveira (LBP), Francisco Langeani (DZSJRP), Carlos and Margarete Lucena (MCP), Paulo Buckup (MNRJ), Mário de Pinna and Osvaldo Oyakawa (MZUSP), Flávio Lima (ZUEC-PIS) and Otávio Froehlich (ZUFMS-PIS) for the loan of specimens and information about material, and other assistance during visits to their institutions. The Núcleo de Pesquisas em Limnologia, Ictiologia e Aquicultura (Nupélia) of the Universidade Estadual de Maringá provided logistic support. The authors are grateful to Flávio Lima and Weferson Graça for critically reading the manuscript. We thank Gabriel Deprá for the confection of the drawings. The Coordenação de Aperfeiçoamento de Pessoal de Nível Superior (CAPES) provided fellowships to LFCT and the Conselho Nacional de Desenvolvimento Científico e Tecnológico (CNPq) provided grants to CSP. MRB and CSP are members of the US National Science Foundation project entitled Planetary Biodiversity Inventory: All Catfish Species Inventory (ACSI).

\section{Literature Cited}

Alexandrou, M. A., C. Oliveira, M. Maillard, R. A. R. McGuill, J. Newton, S. Creer \& M. I. Taylor. 2011. Competition and phylogeny determine community structure in Müllerian co-mimics. Nature, 469: 84-88

Aquino, A. E. \& S. A. Schaefer. 2002. The temporal region of the cranium of loricarioid catfishes (Teleostei: Siluriformes): Morphological diversity and phylogenetic significance. Zoologischer Anzeiger, 241: 223-244.

Arratia, G. \& M. Gayet. 1995. Sensory canals and related bones of tertiary siluriform crania from Bolivia and North America and comparison with recent forms. Journal of Vertebrate Paleontology, 15: 482-505.

Axenrot, T. E. \& S. O. Kullander. 2003. Corydoras diphyes (Siluriformes: Callichthyidae) and Otocinclus mimulus (Siluriformes: Loricariidae), two new species of catfishes from Paraguay, a case of mimetic association. Ichthyological Exploration of Freshwaters, 14: 249-272.

Britto, M. R. 2003. Phylogeny of the subfamily Corydoradinae Hoedeman, 1952 (Siluriformes: Callichthyidae), with a definition of its genera. Proceedings of the Academy of Natural Sciences of Philadelphia, 153: 119-154.

Britto, M. R. \& F. C. T. Lima. 2003. Corydoras tukano, a new species of corydoradine catfish from the rio Tiquié, upper rio Negro basin, Brazil (Ostariophysi: Siluriformes: Callichthyidae). Neotropical Ichthyology, 1: 83-92.

Britto, M. R., F. C. T. Lima \& M. H. Hidalgo. 2007. Corydoras ortegai a new species of corydoradinae catfish from the lower río Putumayo in Peru (Ostariophysi: Siluriformes: Callichthyidae). Neotropical Ichthyology, 5: 293-300.

Britto, M. R., W. B. Wosiacki \& L. F. A. Montag. 2009. A new species of Corydoradinae catfish (Ostariophysi: Siluriformes: Callichthyidae) from Rio Solimões Basin, Brazil. Copeia, 2009: 684-689.

Galves, W., O. A. Shibatta \& F. C. Jerep. 2009. Estudos sobre diversidade de peixes da bacia do alto rio Paraná: uma revisão histórica. Semina, 30: 141-154.

Graça, W. J. \& C. S. Pavanelli. 2007. Peixes da planície de inundação do alto rio Paraná e áreas adjacentes. Maringá, EDUEM.

Langeani, F., R. M. C. Castro, O. T. Oyakawa, O. A. Shibatta, C. S. Pavanelli \& L. Casatti. 2007. Diversidade da ictiofauna do Alto Rio Paraná: composição atual e perspectivas futuras. Biota Neotropica, 7: 1-17.

Maack, R. 1981. Geografia física do Estado do Paraná. Rio de Janeiro, José Olímpio.

Maier, A., C. H. Zawadzki, W. J. Graça \& A. G. Bifi. 2008. Fish, Barra Bonita River, upper Paraná River basin, state of Paraná, Brazil. Check List, 4: 336-340.

Nijssen, H. 1970. Revision of the Surinam catfishes of the genus Corydoras Lacépède, 1803 (Pisces, Siluriformes, Callichthyidae). Beaufortia, 18: 1-75.

Nijssen, H. \& I. J. H. Isbrücker. 1980. A review of the genus Corydoras Lacépède, 1803 (Pisces, Siluriformes, Callichthyidae). Bijdrague Dierkunde, 50: 190-220.

Reis, R. E. 1997. Revision of the Neotropical genus Hoplosternum (Ostariophysi: Siluriformes: Callichthyidae) with the description of two new genera and three new species. Ichthyological Exploration of Freshwaters, 7: 299-326.

Reis, R. E. 1998. Anatomy and phylogenetic analysis of the neotropical callichthyid catfishes (Ostariophysi, Siluriformes). Zoological Journal of the Linnaean Society, 124: 105-168.

Taylor, W. R. \& G. C. Van Dyke. 1985. Revised procedures for staining and clearing small fishes and other vertebrates for bone and cartilage study. Cybium, 9: 107-119.

Submitted June 24, 2013 Accepted November 19, 2013 by Francisco Langeani Published March 31, 2014 